\title{
Pattern of beverage intake and milk and dairy products sufficiency among high-school students in Kuwait
}

M.F. Nassar, ', A.M. AbdelKader, ${ }^{2}$ F.A. Al-Refaee ${ }^{3}$ and S.S. Al-Dhafiri ${ }^{4}$

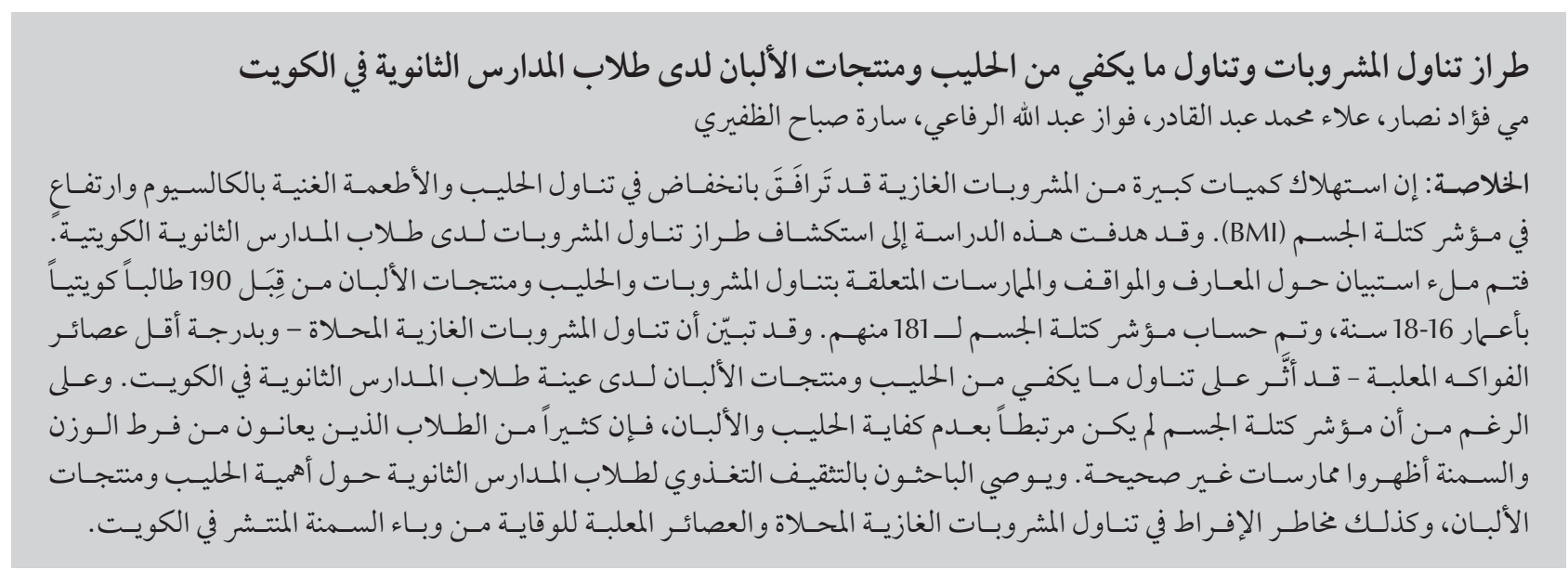

ABSTRACT High consumption of soft drinks has been associated with lower intakes of milk and calcium-rich foods and higher body mass index (BMI). This study aimed to explore the pattern of beverage intake among Kuwaiti high-school students. A questionnaire on knowledge, attitudes and practices concerning beverages and milk and dairy products intake was completed by 190 Kuwaiti students aged 16-18 years and BMI was calculated for 181 of them. Intake of sweetened carbonated beverages and to a lesser extent packaged fruit juices affected the sufficiency of milk and dairy products intake among the sample of high-school students in Kuwait. Although BMI was not related to milk and dairy insufficiency, more of the overweight and obese students displayed incorrect practices. Nutritional education of highschool students on the importance of milk and dairy products as well as the hazards of excess sweetened carbonated beverages and packaged juice is recommended to prevent the obesity epidemic prevailing in Kuwait.

\section{Caractéristiques de la prise de boissons sucrées et suffisance des apports en lait et produits laitiers chez des élèves d'établissements du secondaire au Koweït}

RÉSUMÉ Une consommation élevée de boissons sucrées a été associée à une réduction des apports en lait et aliments riches en calcium ainsi qu'à une élévation de l'indice de masse corporelle. L'étude visait à explorer les caractéristiques de la prise de boissons sucrées chez des élèves du secondaire au Koweït. Un questionnaire sur les connaissances, les attitudes et les pratiques concernant la prise de boissons sucrées, de lait et de produits laitiers a été rempli par 190 élèves du Koweït âgés de 16 à 18 ans, et l'indice de masse corporelle a été calculé pour 181 d'entre eux. La prise de boissons gazeuses sucrées et dans une moindre mesure de jus de fruit préemballés affectait la suffisance des apports en lait et en produits laitiers au sein de l'échantillon d'élèves du secondaire au Koweït. Si l'indice de masse corporelle n'était pas lié à des apports en lait et produits laitiers insuffisants, les élèves en surpoids et obèses étaient plus nombreux à avoir de mauvaises pratiques. Une éducation nutritionnelle des élèves du secondaire sur l'importance du lait et des produits laitiers ainsi que sur les dangers de l'abus de boissons gazeuses sucrées et de jus de fruit préemballés est recommandée afin de prévenir l'épidémie d'obésité prévalente au Koweït.

'Department of Paediatrics, Faculty of Medicine, Ain Shams University, Cairo, Egypt (Correspondence to M.F. Nassar: maie_nassar@yahoo.co.uk). ${ }^{2}$ Department of Paediatrics, Faculty of Medicine, University of Mansoura, Mansoura, Egypt. ${ }^{3}$ Department of Paediatrics; ${ }^{4}$ Department of Food and Nutrition, Al-Adan Hospital, Ministry of Health, Kuwait.

Received: 06/12/13; accepted: 20/05/14 


\section{Introduction}

The dietary habits of schoolchildren and adolescents in Arab countries are nowadays characterized by a low intake of fresh fruits, vegetables and milk with a high intake of carbonated beverages and so-called "fast foods" (1). In Saudi Arabia, carbonated beverages and canned fruit drinks were shown to comprise $26 \%$ and $25 \%$ respectively of adolescents' daily fluid consumption (2). Harrington's review noted that soft drinks' consumption in the UnitedStates(US) hadincreased by $300 \%$ in the last 20 years (3). As children and teenagers get older, boys and girls drink less milk and more soft drinks and fruit juice (4). Vartanian et al. reported that intake of soft drinks was also associated with lower intakes of milk, calcium and other nutrients, with an ensuing increased risk of several medical problems such as diabetes (5). Additionally, Wyshak demonstrated an association between carbonated beverage consumption and bone fractures (6). More recently, Martin-Cavlo et al. (7) and Nasreddine et al. (8) found a strong and significant association between consumption of sugar-sweetened carbonated beverages and a risk of obesity in children and adolescents.

Although data concerning obesity and beverages intake in the Arab region are abundant, research concerning beverage consumption and its effect on the intake of milk and dairy foods is scarce. This study was therefore designed to explore the pattern of beverage intake among high-school students in Al-Ahmadi Governorate, Kuwait, and its effect on the consumption of milk and other dairy products. A secondary objective was to study any relationship between this pattern of beverage intake and the body mass index (BMI) of students.

\section{Methods}

\section{Study design and sample}

The study was performed on 98 girls and 92 boys aged $16-18$ years, enrolled from government high schools in AlAhmadi Governorate, Kuwait, between 1 March and 31 May 2013. Out of 240 high-school students who attended a scientific lecture on healthy eating behaviour in their schools, 190 (79.2\%) were entered in the study.

\section{Data collection}

A dietary questionnaire on nutritional knowledge, food choices and eating behaviour was constructed in simple Arabic language, based on the work of Parmenter and Wardle (9) and Turconi et al. (10). Initially, a pilot study was done by introducing the questionnaire to 10 students chosen at random to assess their comprehension of such data. The questionnaire was modified accordingly and administered to the remaining students.

All questions were multiple choice or Yes/No responses. The questionnaire collected data on the students' sociodemographic characteristics and assessed their knowledge about the benefits and the recommended intake of milk and dairy products ( 2 items); their attitudes to milk and dairy products, i.e. whether they enjoyed consuming them (1 item); and their practices towards milk and other beverages, i.e. sources of milk (home, school), what kinds of milk drunk (cow, soy, camel, goat, milk food supplements), preference for full-or lowfat milk, preference for drinking milk or sugar-sweetened beverages, reasons for choosing milk (5 items). A student's attitude was rated as positive if he or she preferred milk and other dairy products, enjoyed drinking them, believed in their benefits and had no concerns about consuming them. Practice was judged to be correct if milk and other dairy products were available and consumed in preference to other beverages.

A food frequency sheet was included for students to estimate their most recent intake of milk and other dairy products and compare it with the recommended daily allowance (3 cups/day) (11). Regarding fluid milk, intake of 2 cups/day was considered sufficient $(12,13)$. The daily frequency of packaged fruit juice and carbonated beverages use was documented, and consumption was categorized as: heavy $>12$ ounces $(\sim 355 \mathrm{~mL}) /$ day, moderate $8-12$ ounces $(\sim 236-355 \mathrm{~mL}) /$ day or mild $<8$ ounces $(\sim 236 \mathrm{~mL}) /$ day $(14,15)$.

Anthropometric measurements were obtained by the main researcher according to the methods of Lee and Nieman (16), and BMI was calculated using the standard formula (17).

\section{Data analysis}

The collected data were statistically analysed using SPSS, version 20. Descriptive statistics were done for categorical data by numbers and percentages and for continuous data using mean and standard deviation (SD) and median and interquartile range (IQR). The prevalence of intake for a certain items was calculated as the number of cases per 100 students. The chi-squared and Fisher exact tests were used to compare the frequency of qualitative variables among the different groups.

\section{Results}

\section{Beverages intake and milk and dairy products knowledge, attitudes and practice}

A total of 190 students provided data on beverages intake and nutritional practices: 92 (48.4\%) males and 98 (51.6\%) females. The mean age of the students was 17.3 (SD 0.7) years; median age was 17 (IQR 17-18) years.

Sufficient milk and dairy products intake was reported by $30.0 \%$ and $45.3 \%$ of the studied students respectively. Out of all the studied students $36.8 \%$ preferred low-fat milk and other dairy products over full-fat types. Regarding the beverages consumed, $91.6 \%$ drank regular sugar-sweetened beverages and the rest preferred noncalorie-sweetened ("diet") beverages. 
Table 1 shows a significant insuf- beverages $(P=0.019)$; this was more rates of milk insufficiency were seen ficiency in daily milk intake among common in males than females but with higher intakes of packaged fruit drinkers of sweetened carbonated not significantly so $(P=0.063)$. Higher juices, but this also did not reach

\begin{tabular}{|c|c|c|c|c|c|c|c|c|c|c|c|c|}
\hline \multirow{3}{*}{$\begin{array}{l}\text { Beverages intake }{ }^{a} \text { by } \\
\text { sex }\end{array}$} & \multicolumn{4}{|c|}{ Milk intake ${ }^{\mathrm{b}}$} & \multirow[t]{3}{*}{$x^{2}$} & \multirow[t]{3}{*}{$P$-value } & \multicolumn{4}{|c|}{ Dairy products intake } & \multirow[t]{3}{*}{$\chi^{2}$} & \multirow[t]{3}{*}{$P$-value } \\
\hline & \multicolumn{2}{|c|}{ Sufficient } & \multicolumn{2}{|c|}{ Insufficient } & & & \multicolumn{2}{|c|}{ Sufficient } & \multicolumn{2}{|c|}{ Insufficient } & & \\
\hline & No. & $\%$ & No. & $\%$ & & & No. & $\%$ & No. & $\%$ & & \\
\hline \multicolumn{13}{|l|}{ Carbonated beverages } \\
\hline \multicolumn{13}{|l|}{ Males } \\
\hline Mild & 14 & 43.8 & 18 & 56.2 & 5.520 & 0.063 & 17 & 53.1 & 15 & 46.9 & 4.289 & 0.117 \\
\hline Average & 6 & 17.6 & 28 & 82.4 & & & 16 & 47.1 & 18 & 52.9 & & \\
\hline Heavy & 7 & 26.9 & 19 & 73.1 & & & 7 & 26.9 & 19 & 73.1 & & \\
\hline \multicolumn{13}{|l|}{ Females } \\
\hline Mild & 17 & 39.5 & 26 & 60.5 & 2.872 & 0.238 & 24 & 55.8 & 19 & 44.2 & 3.029 & 0.220 \\
\hline Average & 5 & 23.8 & 16 & 76.2 & & & 7 & 33.3 & 14 & 66.7 & & \\
\hline Heavy & 8 & 23.5 & 26 & 76.5 & & & 15 & 44.1 & 19 & 55.9 & & \\
\hline \multicolumn{13}{|l|}{ All students } \\
\hline Mild & 31 & 41.3 & 44 & 58.7 & 7.921 & 0.019 & 41 & 54.7 & 34 & 45.3 & 4.730 & 0.094 \\
\hline Average & 11 & 20.0 & 44 & 80.0 & & & 23 & 41.8 & 32 & 58.2 & & \\
\hline Heavy & 15 & 25.0 & 45 & 75.0 & & & 22 & 36.7 & 38 & 63.3 & & \\
\hline \multicolumn{13}{|l|}{ Packaged fruit juice } \\
\hline \multicolumn{13}{|l|}{ Males } \\
\hline Mild & 11 & 35.5 & 20 & 64.5 & 1.299 & 0.522 & 19 & 61.3 & 12 & 38.7 & 7.182 & 0.028 \\
\hline Average & 8 & 30.8 & 18 & 69.2 & & & 11 & 42.3 & 15 & 57.7 & & \\
\hline Heavy & 8 & 22.9 & 27 & 77.1 & & & 10 & 28.6 & 25 & 71.4 & & \\
\hline \multicolumn{13}{|l|}{ Females } \\
\hline Mild & 13 & 41.9 & 18 & 58.1 & 3.853 & 0.146 & 12 & 38.7 & 19 & 61.3 & 1.409 & 0.494 \\
\hline Average & 8 & 33.3 & 16 & 6.7 & & & 13 & 54.2 & 11 & 45.8 & & \\
\hline Heavy & 9 & 20.9 & 34 & 79.1 & & & 21 & 48.8 & 22 & 51.2 & & \\
\hline \multicolumn{13}{|l|}{ All students } \\
\hline Mild & 24 & 38.7 & 38 & 61.3 & 4.835 & 0.089 & 31 & 50.0 & 31 & 50.0 & 1.672 & 0.433 \\
\hline Average & 16 & 32.0 & 34 & 68.0 & & & 24 & 48.0 & 26 & 52.0 & & \\
\hline Heavy & 17 & 21.8 & 61 & 78.2 & & & 31 & 39.7 & 47 & 60.3 & & \\
\hline \multicolumn{13}{|l|}{ Tea and coffee } \\
\hline \multicolumn{13}{|l|}{ Males } \\
\hline Mild & 11 & 35.5 & 20 & 64.5 & 0.951 & 0.622 & 14 & 45.2 & 17 & 54.8 & 1.999 & 0.368 \\
\hline Average & 10 & 27.8 & 26 & 72.2 & & & 18 & 50.0 & 18 & 50.0 & & \\
\hline Heavy & 6 & 24.0 & 19 & 76.0 & & & 8 & 32.0 & 17 & 68.0 & & \\
\hline \multicolumn{13}{|l|}{ Females } \\
\hline Mild & 16 & 35.6 & 29 & 64.4 & 5.345 & 0.069 & 22 & 48.9 & 23 & 51.1 & 1.234 & 0.540 \\
\hline Average & 13 & 35.1 & 24 & 64.9 & & & 15 & 40.5 & 22 & 59.5 & & \\
\hline Heavy & 1 & 6.2 & 15 & 93.8 & & & 9 & 56.2 & 7 & 43.8 & & \\
\hline All students & & & & & & & & & & & & \\
\hline Mild & 27 & 35.5 & 49 & 64.5 & 4.447 & 0.108 & 36 & 47.4 & 40 & 52.6 & 0.375 & 0.829 \\
\hline Average & 23 & 31.5 & 50 & 68.5 & & & 33 & 45.2 & 40 & 54.8 & & \\
\hline Heavy & 7 & 17.1 & 43 & 82.9 & & & 17 & 41.5 & 24 & 58.5 & & \\
\hline
\end{tabular}

${ }^{a}$ Beverages intake: mild < 8 ounces $(\sim 236 \mathrm{~mL}) /$ day; moderate $8-12$ ounces $(\sim 236-355 \mathrm{~mL}) /$ day; heavy $>12$ ounces $(\sim 355 \mathrm{~mL}) /$ day $(14,15)$.

${ }^{b}$ Milk intake: sufficient $\geq 2$ cups/day; insufficient $<2$ cups/day $(12,13)$.

'Dairy intake: sufficient $\geq 3$ cups/day; insufficient $<3$ cups/day (11). 
statistical significance $(P=0.089)$. A similar trend for milk insufficiency was noticed among the heavy tea and coffee drinkers but, again, without statistical significance $(P=0.108)$. Table 1 also shows that although higher intake of different kinds of beverages was more common in students with dairy intake insufficiency, there was no statistically significant relationship with drinking carbonated beverages, packaged fruit juices or tea and coffee. However, we found a significantly higher intake of packaged fruit juice in male students with dairy insufficiency $(P=0.028)$, an effect which was not evident among female students $(P=0.494)$.

Assessment of knowledge regarding milk and dairy products needs and functions showed that $59.5 \%$ of students had correct knowledge of the needs while $81.6 \%$ had correct knowledge regarding the function. No statistical significant differences were detected when comparing the knowledge of needs or function with respect to sufficiency of other dairy products and milk intake, BMI and sex [data not shown].

Table 2 underscores that significantly more students with sufficient milk intake than those with insufficient intake reported correct practices (59.6\% versus $40.6 \%)(P=0.024)$. Similarly $54.7 \%$ of students with sufficient dairy products intake had correct practice versus $39.4 \%$ of those with insufficient dairy intake and this was close to statistical significance $(P=0.051)$.

Regarding attitudes $69.0 \%$ of the studied students had a positive attitude towards milk and dairy products intake. More students with sufficient milk and dairy intake had a positive attitude than those with insufficient intake, and for milk the relationship nearly reached statistical significance $(P=0.059$ for milk and $P=0.379$ for dairy products).

\section{BMI and beverages and milk and dairy products intake}

Of the surveyed students, 181 had their weight and height assessed; 9 (4.7\%) students ( 1 male and 8 females) refused weight measurement. Among these 87 students (48.1\%) had normal weight, 50 (27.6\%) were overweight, 21 (11.6\%) were underweight, and 23 (12.7\%) were obese. Although more male students were overweight and obese compared with female students, there was no significant difference in BMI between the sexes $(P=0.078)$ [data not shown].

There were no significant differences in BMI among students with respect to dairy intake $(P=0.264)$, milk intake ( $P$ $=0.180)$, drinking carbonated beverage $(P=0.231)$, packaged fruit juice usage $(P=0.591)$ or tea and coffee intake $(P=$ 0.418) [data not shown].

Table 2 shows that although more obese (66.0\%) and overweight (53.2\%) students reported incorrect practice compared with normal (47.1\%) and underweight (46.7\%) students this result did not reach statistical significance $(P=0.183)$.

\section{Discussion}

The present study revealed a statistically significant insufficiency in daily milk intake among students who drank sweetened carbonated beverages, an effect which was more evident in males than females. Although carbonated beverages intake did not significantly affect dairy products intake, package fruit juice intake in males was significantly associated with dairy insufficiency. Blum et al. reported significant decreases in milk consumption in children who consumed soft drinks (18). Marshall et al. also found that milk intakes were inversely associated with intakes of juice drinks, carbonated drinks and addedsugar beverages (19). Recently, Libuda et al. reported that the consumption of all soft drinks has a bone catabolic effect and was negatively associated with total protein and milk consumption (20).

The current study showed that $27.6 \%$ of the included students were overweight while $12.7 \%$ were obese, figures which are close to the reported prevalence of obesity in the USA (16.9\% in children and adolescents in 2009-10) (21). In Kuwait, Al-Refaee et al. also published close figures in a younger coherent $(21.3 \%$ were at risk of overweight and $14.4 \%$ were overweight) (22).

There was no significant difference in BMI among the studied students with respect to milk or dairy intake. In the United Arab Emirates, Kerdaki et al. reported a low prevalence of daily consumption of milk yet could not correlate this with overweight among female schoolchildren (23). On the other hand in Portugal, Abreu et al. found an inverse association between milk intake and both BMI and percentage body fat in adolescent girls (24), but, elsewhere, there is only moderate quality evidence that dairy products supplementation stimulates linear growth (25). Our findings are consistent with Lin et al. in Hong Kong who reported a lack of association between milk or other dairy products consumption and BMI and suggested that the negative association observed in Western populations may be due to confounding by socioeconomic status (26).

The current study found no significant difference in BMI and the amount of carbonated beverages, packaged fruit juices or tea and coffee consumed. Similarly, Rajeshwar et al. reported no significant association between soft drinks consumption and BMI (27). The consumption of sugar-sweetened beverages has been linked to rising rates of obesity in the USA as these drinks are less satiating than solid foods (28). A study from Saudi Arabia reported an association between sugar-sweetened carbonated beverages intake and BMI in 10-19-year-old boys and that their beverage intake correlated with poor dietary choices (29).

Poor knowledge did not seem to affect milk and dairy intake among the studied high-school students, but more 


\begin{tabular}{|c|c|c|c|c|c|c|}
\hline \multirow{3}{*}{$\begin{array}{l}\text { Milk/dairy sufficiency }{ }^{\mathrm{a}, \mathrm{b}} \text { and BMI } \\
\text { categoryc by sex }\end{array}$} & \multicolumn{4}{|c|}{ Practice $^{d}$} & \multirow[t]{3}{*}{$x^{2}$} & \multirow[t]{3}{*}{$P$-value } \\
\hline & \multicolumn{2}{|c|}{ Correct } & \multicolumn{2}{|c|}{ Incorrect } & & \\
\hline & No. & $\%$ & No. & $\%$ & & \\
\hline \multicolumn{7}{|l|}{ Milk intake } \\
\hline \multicolumn{7}{|l|}{ Males } \\
\hline Sufficient & 16 & 59.3 & 11 & 40.7 & \multirow{2}{*}{3.017} & \multirow{2}{*}{0.082} \\
\hline Insufficient & 24 & 36.9 & 41 & 63.1 & & \\
\hline \multicolumn{7}{|l|}{ Females } \\
\hline Sufficient & 18 & 60.0 & 12 & 40.0 & \multirow{2}{*}{1.514} & \multirow{2}{*}{0.219} \\
\hline Insufficient & 30 & 44.1 & 38 & 55.9 & & \\
\hline \multicolumn{7}{|l|}{ All students } \\
\hline Sufficient & 34 & 59.6 & 23 & 40.4 & \multirow{2}{*}{5.081} & \multirow{2}{*}{0.024} \\
\hline Insufficient & 54 & 40.6 & 79 & 59.4 & & \\
\hline \multicolumn{7}{|l|}{ Dairy products intake } \\
\hline \multicolumn{7}{|l|}{ Males } \\
\hline Sufficient & 23 & 57.5 & 17 & 42.5 & \multirow{2}{*}{4.697} & \multirow{2}{*}{0.030} \\
\hline Insufficient & 17 & 32.7 & 35 & 67.3 & & \\
\hline \multicolumn{7}{|l|}{ Females } \\
\hline Sufficient & 24 & 52.2 & 22 & 47.8 & \multirow{2}{*}{0.154} & \multirow{2}{*}{0.695} \\
\hline Insufficient & 24 & 46.2 & 28 & 53.8 & & \\
\hline \multicolumn{7}{|l|}{ All students } \\
\hline Sufficient & 47 & 54.7 & 39 & 45.3 & \multirow{2}{*}{3.799} & \multirow{2}{*}{0.051} \\
\hline Insufficient & 41 & 39.4 & 63 & 60.6 & & \\
\hline BMI category & & & & & & \\
\hline Males & & & & & & \\
\hline Underweight & 3 & 50.0 & 3 & 50.0 & & \\
\hline Normal & 19 & 45.2 & 23 & 54.2 & 1424 & 0700 \\
\hline Overweight & 10 & 35.7 & 18 & 64.3 & & \\
\hline Obese & 8 & 53.3 & 7 & 46.7 & & \\
\hline Females & & & & & & \\
\hline Underweight & 8 & 53.3 & 7 & 46.7 & & \\
\hline Normal & 27 & 60.0 & 18 & 40.0 & 5276 & 0153 \\
\hline Overweight & 7 & 31.8 & 15 & 68.2 & 0.270 & 0.135 \\
\hline Obese & 3 & 37.5 & 5 & 62.5 & & \\
\hline All students & & & & & & \\
\hline Underweight & 11 & 52.4 & 10 & 47.6 & & \\
\hline Normal & 46 & 52.9 & 41 & 47.1 & 4848 & 0183 \\
\hline Overweight & 17 & 34.0 & 33 & 66.0 & 4.040 & 0.105 \\
\hline Obese & 11 & 47.8 & 12 & 52.2 & & \\
\hline
\end{tabular}

aMilk intake: sufficient $\geq 2$ cups/day; insufficient $<2$ cups/day $(12,13)$

${ }^{b}$ Dairy intake: sufficient $\geq 3$ cups/day; insufficient $<3$ cups/day (11).

${ }^{c}$ BMI categories: underweight $<18.5 \mathrm{~kg} / \mathrm{m}^{2} ;$ normal $18.5-24.9 \mathrm{~kg} / \mathrm{m}^{2}$; overweight $25-29.9 \mathrm{~kg} / \mathrm{m}^{2} ;$ obese $>30 \mathrm{~kg} / \mathrm{m}^{2}$.

'Practice: correct when milk was chosen over other, sweetened beverages.

students with sufficient milk intake reported correct practices. It was also evident that more males who had insufficient milk and dairy intake reported incorrect practices, with more obese and overweight students displaying improper practice too. Luckily, the attitude of the majority of students (69.0\%) towards milk and dairy products was positive. Du et al. indicated that milk had a beneficial effect on bone mass and suggested that promotion of milk consumption should be considered for achieving optimal bone mineral content (30). 
In conclusion, the intake of sweetened carbonated beverages and to a lesser extent packaged fruit juices are affecting the sufficiency of milk and dairy intake among our high-school student sample in Al-Ahmadi, Kuwait. While our results cannot be generalised to the overall high-school student population in Kuwait, they may suggest a wider problem as our students are not untypical of Kuwait high-school students. Although BMI was not related to insufficient milk and dairy intakes, more overweight and obese students displayed incorrect practices. This emphasizes the importance of improving nutrition practices to achieve the goal of prevention of the obesity epidemic in Kuwait. We thus recommend nutritional education of high-school students, laying stress on the milk and dairy products needed as well as the dangers of excess sweetened carbonated beverages and packaged juice intake. This recommendation is coupled with a plea for government and nongovernmental decision-makers to highlight the magnitude of improper beverage consumption and warn against its hazards.

Competing interests: None declared.

\section{References}

1. Musaiger AO. Diet and prevention of coronary heart disease in the Arab Middle East countries. Med Princ Pract. 2002;11 Suppl 2:9-16. PMID:12444306

2. Bello LL, Al-Hammad N. Pattern of fluid consumption in a sample of Saudi Arabian adolescents aged 12-13 years. Int J Paediatr Dent. 2006 May;16(3):168-73. PMID:16643537

3. Harrington S. The role of sugar-sweetened beverage consumption in adolescent obesity: a review of the literature. J Sch Nurs. 2008 Feb;24(1):3-12. PMID:18220450

4. Garriguet D. Beverage consumption of children and teens. Health Rep. 2008 Dec;19(4):17-22. PMID:19226923

5. Vartanian LR, Schwartz MB, Brownell KD. Effects of soft drink consumption on nutrition and health: a systematic review and meta-analysis. Am J Public Health. 2007 Apr;97(4):66775. PMID:17329656

6. Wyshak G. Teenaged girls, carbonated beverage consumption, and bone fractures. Arch Pediatr Adolesc Med. 2000 Jun;154(6):610-3. PMID:10850510

7. Martin-Calvo N, Martínez-González MA, Bes-Rastrollo M, Gea A, Ochoa MC, Marti A; GENOI Members. Sugar-sweetened carbonated beverage consumption and childhood/ adolescent obesity: a case-control study. Public Health Nutr. 2014 Jan 31;31:1-9. PMID:24485091

8. Nasreddine L, Naja F, Akl C, Chamieh MC, Karam S, Sibai AM, Hwalla N. Dietary, lifestyle and socio-economic correlates of overweight, obesity and central adiposity in Lebanese children and adolescents. Nutrients. 2014, 10;6(3):1038-62.

9. Parmenter K, Wardle J. Development of a general nutrition knowledge questionnaire for adults. Eur J Clin Nutr. 1999 Apr;53(4):298-308. PMID:10334656

10. Turconi G, Celsa M, Rezzani C, Biino G, Sartirana MA, Roggi C. Reliability of a dietary questionnaire on food habits, eating behaviour and nutritional knowledge of adolescents. Eur J Clin Nutr. 2003 Jun;57(6):753-63. PMID:12792659

11. Gidding SS, Dennison BA, Birch LL, Daniels SR, Gillman $\mathrm{MW}$, Lichtenstein $\mathrm{AH}$, et al.; American Heart Association; American Academy of Pediatrics. Dietary recommendations for children and adolescents: a guide for practitioners: consensus statement from the American Heart Association. Circulation. 2005 Sep 27;112(13):2061-75. PMID:16186441

12. Nucci AM, Russell CS, Luo R, Ganji V, Olabopo F, Hopkins B, et al. The effectiveness of a short food frequency questionnaire in determining vitamin D intake in children. Dermatoendocrinol. 2013 Jan 1;5(1):205-10. PMID:24494056

13. Maguire JL, Lebovic G, Kandasamy S, Khovratovich M, Mamdani M, Birken CS, et al.; TARGet Kids! Collaboration. The relationship between cow's milk and stores of vitamin D and iron in early childhood. Pediatrics. 2013 Jan;131(1):e144-51. PMID:23248224

14. Mrdjenovic G, Levitsky DA. Nutritional and energetic consequences of sweetened drink consumption in 6- to 13-year-old children. J Pediatr. 2003 Jun;142(6):604-10. PMID:12838186

15. Popkin BM, Armstrong LE, Bray GM, Caballero B, Frei B, Willett WC. A new proposed guidance system for beverage consumption in the United States. Am J Clin Nutr. 2006 Mar;83(3):529-42. PMID:16522898

16. Lee RD, Nieman DC, editors. Nutritional assessment. 3rd ed. New York: McGraw-Hill; 2003. pp. 164-75.

17. Skelton JA, Rudolf CD. Chapter 44: Overweight and obesity. In: Behrman RE, Kliegman RM, Jenson HB, Stanton BF, editors. Nelson Textbook of Pediatrics. 18th ed. Philadelphia: Saunders Elsevier; 2008.

18. Blum JW, Jacobsen DJ, Donnelly JE. Beverage consumption patterns in elementary school aged children across a two-year period. J Am Coll Nutr. 2005 Apr;24(2):93-8. PMID:15798075

19. Marshall TA, Eichenberger Gilmore JM, Broffitt B, Stumbo PJ, Levy SM. Diet quality in young children is influenced by beverage consumption. J Am Coll Nutr. 2005 Feb;24(1):65-75. PMID:15670987

20. Libuda L, Alexy U, Remer T, Stehle P, Schoenau E, Kersting M. Association between long-term consumption of soft drinks and variables of bone modeling and remodeling in a sample of healthy German children and adolescents. Am J Clin Nutr. 2008 Dec;88(6):1670-7. PMID:19064530

21. Ogden CL, Carroll MD, Kit BK, Flegal KM. Prevalence of obesity and trends in body mass index among US children and adolescents, 1999-2010. JAMA. 2012 Feb 1;307(5):483-90. PMID: 22253364

22. Al-Refaee FA, Al-Qattan SA, Jaber SM, Al-Mutairi AA, AlDhafiri SS, Nassar MF. The rising tide of overweight among Kuwaiti children: study from Al-Adan Hospital, Kuwait. Med Princ Pract. 2013;22:600-2. PMID:23735665

23. Kerkadi A, Abo-Elnaga N, Ibrahim W. Prevalence of overweight and associated risk factors among primary female school children in Al-Ain city United Arab Emirates. Emirates Journal of Agricultural Sciences. 2005;17(1):43-56.

24. Abreu S, Santos R, Moreira C, Santos PC, Vale S, Soares-Miranda $L$, et al. Milk intake is inversely related to body mass index and body fat in girls. Eur J Pediatr. 2012 Oct;171(10):1467-74. PMID:22547119

25. De Beer H. Dairy products and physical stature: a systematic review and meta-analysis of controlled trials. Econ Hum Biol. 2012 Jul;10(3):299-309. PMID:21890437 
26. Lin SL, Tarrant M, Hui LL, Kwok MK, Lam TH, Leung GM, et al. The role of dairy products and milk in adolescent obesity: evidence from Hong Kong's "Children of 1997" birth cohort. PLoS One. 2012;7(12):e52575. PMID:23285099

27. Rajeshwari R, Yang SJ, Nicklas TA, Berenson GS. Secular trends in children's sweetened-beverage consumption (1973 to 1994): the Bogalusa Heart Study. J Am Diet Assoc. 2005 Feb;105(2):208-14. PMID:15668676

28. Drewnowski A, Bellisle F. Liquid calories, sugar, and body weight. Am J Clin Nutr. 2007 Mar;85(3):651-61. PMID:17344485
29. Collison KS, Zaidi MZ, Subhani SN, Al-Rubeaan K, Shoukri M, Al-Mohanna FA. Sugar-sweetened carbonated beverage consumption correlates with BMI, waist circumference, and poor dietary choices in school children. BMC Public Health. 2010;10:234. PMID:20459689

30. Du XQ, Greenfield H, Fraser DR, Ge KY, Liu ZH, He W. Milk consumption and bone mineral content in Chinese adolescent girls. Bone. 2002 Mar;30(3):521-8. PMID:11882468 